http://kitaibelia.unideb.hu/

ISSN 2064-4507 (Online) • ISSN 1219-9672 (Print)

(C) Department of Botany, University of Debrecen, Hungary

26(2): 145-156.; 2021

DOI: $10.17542 /$ kit.26.145

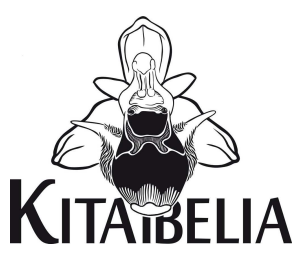

\title{
A Vulpia ciliata morfológiája és magyarországi terjedésének sikere a vasúthálózat mentén
}

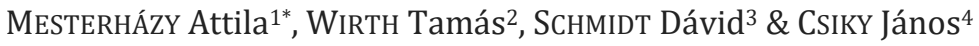 \\ (1) Ökológiai Kutatóintézet, Vízi Ökológiai Intézet, Tisza Kutató Osztály, H-4026 Debrecen, Bem tér 18/C; \\ *amesterhazy@gmail.com \\ (2) PTE Botanikus Kert, H-7624 Pécs, Ifjúság útja 6. \\ (3) Soproni Egyetem, Erdőmérnöki Kar, Növénytani és Természetvédelmi Intézet, H-9400 Sopron, Bajcsy-Zsilinszky u. 4. \\ (4) Pécsi Tudományegyetem TTK Biológiai Intézet, Ökológiai Tanszék, H-7624 Pécs Ifjúság u. 6.
}

\section{Spreading along the railways: morphology and invasion success of Vulpia ciliata in Hungary}

Abstract - Vulpia ciliata Dumort, a widespread species in the Mediterranean region, has been introduced in several European countries in recent decades, mainly along railways. The species was first discovered in Hungary at Szolnok railway station in May 2016, then a few days later at Keleti railway station in Budapest. In 2020 the species was found in several Transdanubian railway stations. Apparently, V. ciliata has recently been established in numerous parts of the country, probably spreading by railway transport. Until now, the species has only been found in the vicinity of regularly used tracks (in a distance of $20 \mathrm{~m}$ at the most). Being an invasive alien species, V. ciliata can displace the native Vulpia myuros in ruderal vegetation along railway lines. The species can easily be distinguished from $V$. myuros by its hairy lemma. Moreover, it flowers earlier than the other two indigenous species in Hungary, often already in late April. Based on the characteristics examined (number of nodes in the upper $2 \mathrm{~cm}$ zone of the rachis, number of fruits per spikelet, rate of fertile and sterile florets within the spikelet, lower and upper glume length, lemma and awn length separately, rachis width in the upper $2 \mathrm{~cm}$ zone) we have concluded that $V$. bromoides and $V$. myuros are less different from each other than $V$. ciliata from these two species. In the case of $V$. ciliata subsp. ciliata, we observed that spikelets (detached from the inflorescens) function as dispersal units. Therefore we assume that the observed low fertility rate within the spikelets, as well as the presence of marginal cilia on lemmas promote the spreading success of $V$. ciliata (spreading in clusters, anemochory, zoochory, anthropochory). Its early maturation (in May) can also facilitate its spread along railways, because the populations survive the chemical weed control usually carried out in late spring. The other two Hungarian species usually ripen later (in June). For the time being, the spread of $V$. ciliata outside the Hungarian railway network may be hindered by climatic conditions, or by the lack of seasonal weed control outside that network, which otherwise offers a relative survival advantage for $V$. ciliata along railway tracks.

Keywords: foxtail fescue, Hungarian flora, introduced species, invasion success, railway station

Összefoglalás - A Mediterráneumban elterjedt Vulpia ciliata Dumort Európa több országában, jellemzően vasutak mentén jelent meg az elmúlt évtizedekben. A fajt 2016 tavaszán észleltük először Magyarországon, a szolnoki vasútállomáson, majd néhány nappal később Budapest-Keleti pályaudvaron. A faj 2020-ban számos más dunántúli vasútállomáson is megtaláltuk, és úgy tűnik, hogy napjainkra az ország jelentős részén megtelepedett. A $V$. ciliata ezidáig csak a rendszeresen használt vágányok közeléből (max. 20 m-es távolságon belül) került elő, feltehetően a vasúti áruszállítással jutott be az országba, és terjedt el. A faj nálunk már meghonosodottnak tekinthető, özönfajként egyelőre még csak a vasút menti ruderális vegetációban lép fel, ahol az őshonos Vulpia myuros-t ki is szoríthatja. A faj a szőrös 
toklászai alapján a hasonló termőhelyen gyakori $V$. myuros-tól egyértelműen megkülönböztethető. Virágzása a két másik fajnál korábban, gyakran már áprilisban elkezdődik. A vizsgált morfológiai jellegek alapján (padkák száma a buga csúcsának 2 cm-es szakaszán, termések száma/füzérke, fertilis virágok aránya/füzérke, alsó és felső pelyvahossz, toklász- és szálkahossz, buga fôtengelyének vastagsága a csúcsi $2 \mathrm{~cm}$-es szakaszon) megállapítható, hogy a $V$. bromoides és $V$. myuros kevésbé különbözik egymástól, mint a $V$. ciliata e két fajtól. Feltételezhető továbbá, hogy a füzérkén belüli alacsony fertilitási arány, a toklászok pillássága összefüggésbe hozható a faj terjedési sikerével (csoportos terjedés, anemochória, zoochória, antropochória). Korai (májusi) termésérése is kedvez a vasút menti terjedésnek, ui. így a többi hasonló fajjal szemben már terméses állapotban vészelheti át a késő tavasszal kezdődő gyomirtást. A vasúthálózaton kívüli magyarországi terjedését egyelőre akadályozhatják a klimatikus viszonyok, illetve a pályatesteken kívüli, relatív előnyt kínáló szezonális gyomirtások hiánya.

Kulcsszavak: behurcolt fajok, egércsenkesz, inváziós siker, magyar flóra, vasútállomás

\section{Bevezetés}

A globális kereskedelem növekedésével az utóbbi évtizedekben a vasúton történő nemzetközi árufuvarozás aránya is megemelkedett hazánkban. Ennek megfelelően a magyarországi vasúti teherforgalom mintegy 50\%-a ma már külföldre irányul (ANON. 2019). A vasúti szállítmányok szerepe a növényfajok terjesztésében jelentős, a szerelvényekkel behurcolódott fajok leginkább a vágányok közelében lévő zavart élőhelyeken jelennek meg, és gyakran el is terjednek. A tehervonatokkal érkező növények magjai leginkább a vasútállomásokon, rendezőpályaudvarokon jelennek meg, ott, ahol a vagonokat időszakosan megállítják, és az árut átpakolják (HANSEN \& CLEVENGER 2005). A szállítmányokon nem csak távoli földrészekről származó idegenhonos fajok érkeznek, hanem gyakran őshonos fajok is, amelyek lehetővé teszik a kultúrtájak természetes élőhelyfoltjai közötti összeköttetést, rekolonizációt (PENONE et al. 2012). A vasúti töltéseken lévő gyepek kapcsolatot teremthetnek a természetközeli élőhelyfragmentumok között (Päıvı et al. 2001), ezért a vasutak szerepe természetvédelmi szempontból kettős: funkcionálhatnak ökológiai folyosóként, de egyúttal segítik az idegenhonos fajok behurcolását is. Az utóbbi évtizedekben Magyarországon főleg az utóbbi szerepük miatt kerültek előtérbe.

A vasúti teherforgalommal behurcolt növényekkel nálunk legelőször Polgár Sándor foglalkozott, aki már az 1900-as évek elején megfigyelt Dél-Amerikából származó adventív növényeket Győrben, a Mosoni-Duna partján lévő gabonaraktár és a hozzá vezető ipari szárnyvasút mellett. Ezek a döntően trópusokról behurcolódott növények tartósan nem tudtak a területen megtelepedni (SCHMIDT 2016). Az 1950-es években Károlyi Árpád Nagykanizsa környéki kutatásai során megfigyelte, hogy a Rijeka-Budapest vasútvonal mentén, azokon a helyeken, ahol a vágányok nyílt élőhelyeken haladnak át, több mediterrán és balkáni flóraelem található meg, mint másutt. Ebből arra a következtetésre jutott, hogy a szélnek jobban kitett részeken a gabonaszállítmányokról a magokat a szél a vágány mellé fújja, így a gabonafélékkel érkező gyommagvak is megjelennek a vasút menti nyílt vegetációtípusokban (BENEDEK \& BUDA 2000).

A 2000-es évek elejétől a vasutak mentén terjedő fajok észlelése megszaporodott. Először DANCZA \& KIRÁlY (2000) tudósított a dél-afrikai származású Senecio inaequidens magyarországi megjelenéséről és terjedéséről, majd később MESTERHÁZY (2006) a Mediterráneumból származó Geranium purpureum esetében mutatott ki hasonló jelenséget. Legutóbb az Európa déli részein élő Galium murale került elő Budapesten, a Keleti pályaudvar egyik mellékvágányáról (BALOGH \& MESTERHÁZY 2017). A vasutak mentén eddig megjelent idegenhonos fajok közül a Geranium purpureum (Mesterházy ined.) és a Senecio inaequidens meghonosodottnak tekinthető (HASZONITS \& SCHMIDT 2018), míg a közelmúltban kimutatott Galium murale-nek egyelőre nem találták újabb hazai populációját (Mesterházy ined.). 
MESTERHÁZY et al. (2021): A Vulpia ciliata morfológiája és magyarországi terjedésének sikere a vasúthálózat mentén

A vasút mellett terjedő fajok között 2016-ban a környékbeli országokból már jól ismert Vulpia ciliata-t is felfedeztük Magyarországon.

\section{Anyag és módszer}

A hazai vasútállomásokat lakhelyünk és az egyéb megbízásaink, teendőink helyszíneinek megfelelően jártuk be. Szisztematikus, reprezentatív mintagyűjtésre nem vállalkoztunk. A különböző helyszíneken gyüjtött példányainkat köz- és magángyüjteményekben helyeztük el (BP, JPU), illetve az állományokat helyszíni fotókkal is dokumentáltuk. A lelőhelyekhez a pontos helyszínek leírásain túl KEF kódokat is rendeltünk. A JPU-ban elhelyezett példányok (1. táblázat) morfológiai, fénymikroszkópos vizsgálatát és fotózását a PTE TTK Biológiai Intézetében, Leica DMS1000 digitális mikroszkóppal végeztük. A herbáriumi lapokon található példányokról véletlenszerúen kiválasztott, karakterenként (pelyva, toklász, szálka, füzérkehossz, termésszám/füzérke; buga főtengelyének felső $2 \mathrm{~cm}$-én található padkák száma, buga főtengelyének vastagsága) 5-5 mérést végeztünk (hosszak, szélességek esetében 10 $\mu \mathrm{m}$-es pontossággal). Megjegyzésre érdemes, hogy a Vulpia-k elkülönítésében használatos szálka- és toklászhossz mérése nem reprodukálható egyértelműen. A toklász és a szálka ui. élesen nem különíthető el, mivel a szálka valójában a fokozatosan elvékonyodó toklász csúcsának közvetlen folytatása. A dolgozatban szereplő méréseknél ezt úgy oldottuk meg, hogy a szálkát attól a ponttól mértük, ahol a mikroszkóp alatt a szálkának oldalról már nem észlelhető elkülönülő szárnya. Ez a pont közvetlenül a belső toklász csúcsa feletti régióban található. A $V$. ciliata esetében ez egybeesik azzal a ponttal, ahol a marginális pillák eltúnnek a toklász csúcsi régiójában. A három faj morfológiai bélyegei közötti különbségek mértékét a PAST programban, Kruskal-Wallis teszttel, illetve Mann-Whitney teszttel vizsgáltuk (HAMMER et al. 2001). A fajonkénti átlagok, minimum- és maximumértékek alapján (2. táblázat) az aktuális irodalmakban szereplő morfológiai leírásokat a megfelelő helyeken módosítottuk, kiegészítettük.

1. táblázat A mérésekhez, fotózáshoz és statisztikai számításokhoz felhasznált hazai példányok adatai Table 1 Data of Hungarian specimens used for measurements, photography and statistical calculations

\begin{tabular}{llllll}
\hline & $\begin{array}{c}\text { Dátum / } \\
\text { Date }\end{array}$ & $\begin{array}{l}\text { Település / } \\
\text { Settlement }\end{array}$ & $\begin{array}{c}\text { Lelőhely / } \\
\text { Locality }\end{array}$ & Leg. \& det. & $\begin{array}{c}\text { KEF / } \\
\text { CEU }\end{array}$ \\
\hline V. ciliata & 2020.05 .18$. & Pécs & „Fópályaudvar” & Csiky János & 9975.1 \\
V. ciliata & 2020.05 .20$. & Pécs & „Külvárosi vá.” & Csiky János & 9975.1 \\
V. ciliata & 2020.05 .20$. & Pécs & „Mecsekalja-Cserkút vá.” & Csiky János & 9975.2 \\
V. bromoides & 2013.05 .25$. & Cserkút & Falu K-i határa & Csiky János & 9974.2 \\
V. bromoides & 2011.06 .09$. & Pécs & „Szabolcs: Csertető” & Csiky János & 9875.4 \\
V. bromoides & $1900.06-07$. & Kőszeg & Kőszeg körül & Waisbecker Antal & 8665.1 \\
V. myuros & 2020.05 .20$. & Pécs & „Pécsbánya-Rendező vá.” & Csiky János & 9975.2 \\
V. myuros & 1956.06 .20$. & Hosszúhetény & Zengó & Uherkovich Gábor & 9876.1 \\
V. myuros & 2020.05 .20$. & Pécs & „Külvárosi vá.” & Csiky János & 9975.1 \\
\hline
\end{tabular}

\section{Elterjedési területe}

A Mediterráneumban őshonos Vulpia ciliata Dumort-t Franciaországból írták le. Természetes elterjedése nyugatról kelet felé, a francia Bretagne-tól a Krím-félszigeten és a Kaszpi-tenger környékén át Nyugat-Kazahsztánig (CоTTON \& STACE 1976), míg a Fekete-tengertől délre Törökországtól Irakon keresztül egészen Pakisztán nyugati részéig tart (BoR 1968). ÉszakAfrikában Marokkótól Líbiáig fordul elő (MAIRE 1955). Közép- és Kelet-Európában a faj őshonos areája északon Románia délnyugati részéig húzódik (CiocÂRLAN 2009), illetve megta- 
lálható Horvátország és Szlovénia tengerparti régióiban (JogAn et al. 2001). PIGNATTi (2017) szerint szinte egész Olaszországban őshonos, bár Észak-Olaszországban ritkának tartja. DélTirolban már adventív (FISCHER et al. 2008). Az ezredfordulón PoLDiNi (2002) a faj északolaszországi, enyhe északi irányú terjeszkedéséről számol be. Franciaországban Lyon és Bordeaux közötti vonaltól délre Burgundia felé, a párizsi medencéig, valamint a Loirevölgytől nyugatra Bretagne-ig tekintik őshonosnak (TISON \& DE FouCAULT 2014). A kanáriszigeteki előfordulásokat adventívnek tartják (VALDÉs \& SCHOLZ 2009). Németországban a subsp. ciliata napjainkra már meghonosodott Baden-Württemberg, Bajorország, Hessen, Alsó-Szászország, Észak-Rajna-Vesztfália és Mecklenburg-Nyugat-Pomeránia tartományokban (BUTTLER et al. 2017). Dánia déli részéről is néhány helyről már ismert (ASMUSSEN-LANGE \& HERMAnN 2016). Belgiumban Wallonia (Boussu, Châtelet, Seilles, Vaulx) egyes részein szintén tartósan megtelepedett (GHIO 1978, VERLOOVE 2021). Svájcban Zürich vasútállomásán észlelték 1918-ban (LANDOLT 2013), azóta főleg az ország nyugati-északnyugati részein terjedt el (LAUBER et al. 2018). Ausztriában a vasutak mentén először 2009-ben jelent meg Salzburg városában, azóta már Alsó-Ausztria, Bécs és Salzburg tartományokban számos előfordulása ismert (REICH et al. 2018). Csehországban alkalmi adventív fajnak tartják (PYŠEK et al. 2012).

Európán kívül az 1900-as évek közepén megtelepedett Ausztrália Victoria államában (WILLIS 1970), majd a kontinens délnyugati részén el is terjedt (JESSOP et al. 2008). A faj 2004ben megjelent az USA-ban is, ahol Utah államban, az Odgen-öböl környékéről került elő (floranorthamerica.org).

A fajnak két alfaja ismert. A törzsalak mellett szintén Franciaországból írták le a subsp. ambigua (Le Gall) Stace \& Auquier-t. Amíg a subsp. ciliata az egész elterjedési területen gyakori, addig a subsp. ambigua előfordulása a faj areájának északnyugati peremére korlátozódik: a belga és a francia tengerpartra, valamint az átellenben lévő angliai tengerpartra (COTTON \& STACE 1976) és a Csatorna-szigetekre (WATKINSON et al. 1998). Ez az alfaj kifejezetten tengerparti nyílt élőhelyeken fordul elő (STACE 2010). Hollandiában mindkét alfaj 1975 és 2000 között honosodott meg (TAMIS 2005).

\section{Morfológiai jellemzés}

A V. ciliata egyéves, lazán gyepes növény, szára (1-)6-45 cm. Levele kopasz, nyelvecske 0,20,5 mm hosszú; lemeze 3,5-10 cm hosszú, 0,4 mm széles, széle begöngyölt. Virágzat (1-)3$20 \mathrm{~cm}$ hosszú, 0,3-1,5 cm széles, a virágzat alsó részét a felső levélhüvely részben körülveszi. A nóduszonkénti bugaágszáma egy. A szálka nélküli füzérke 5-10,5 mm hosszú, (3-)4-10 virággal. Pelyva kopasz, az alsó pelyva $0,1-1,3 \mathrm{~mm}$, hossza kevesebb, mint $1 / 3-\mathrm{a}$ a felső pelyvának. Felső pelyva 1,5-4 mm; toklász 4-7,7 mm hosszú, 3(5) erü, általában pelyhes, szegélye szőrös. A szőrök $1 \mathrm{~mm}$ hosszúak. Toklász csúcsán „eredő” szálka 6-15,3 mm hosszú; belső toklász kissé rövidebb a külső toklásznál; porzó 0,4-0,6(-1,6) mm hosszú. Mag 3,4-6,5 mm hosszú. A faj habitusát és füzérkéjét az 1. ábrán mutatjuk be.

Méréseink alapján a $V$. ciliata markánsan elkülönül a $V$. bromoides-től és $V$. myuros-tól a buga főtengelyének felső $2 \mathrm{~cm}$-én található padkák számában (2. ábra), a füzérkében található termések számában, a fertilis és sterilis virágok arányában, az alsó és a felső pelyva, valamint a toklász szálkájának hosszában (3. ábra), illetve a buga főtengelyének vastagságában. A toklász szálka nélküli hosszában nem különbözik a $V$. bromoides-től, ebben a jellegben szignifikáns módon csak a $V$. myuros-tól tér el (2. és 3. táblázat). A vizsgált jellegek alapján megállapítható, hogy a $V$. bromoides és $V$. myuros kevésbé különbözik egymástól, mint a $V$. ciliata e két fajtól. 


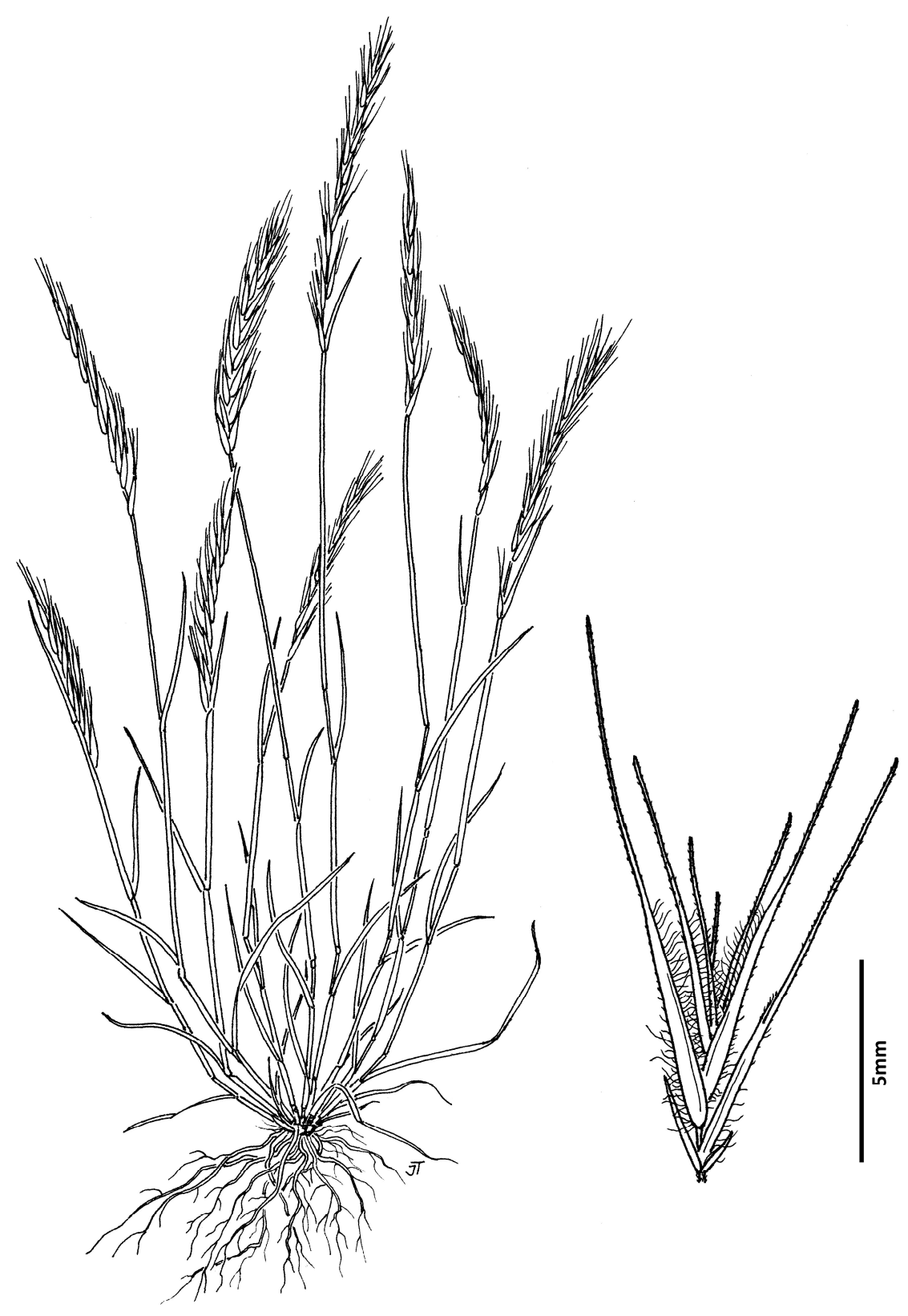

1. ábra A Vulpia ciliata subsp. ciliata habitusrajza, kinagyított füzérkével (Jana Táborská eredeti rajza) Fig. 1 Vulpia ciliata subsp. ciliata, habit and an enlarged spikelet on the right (original drawings of Jana Táborská) 


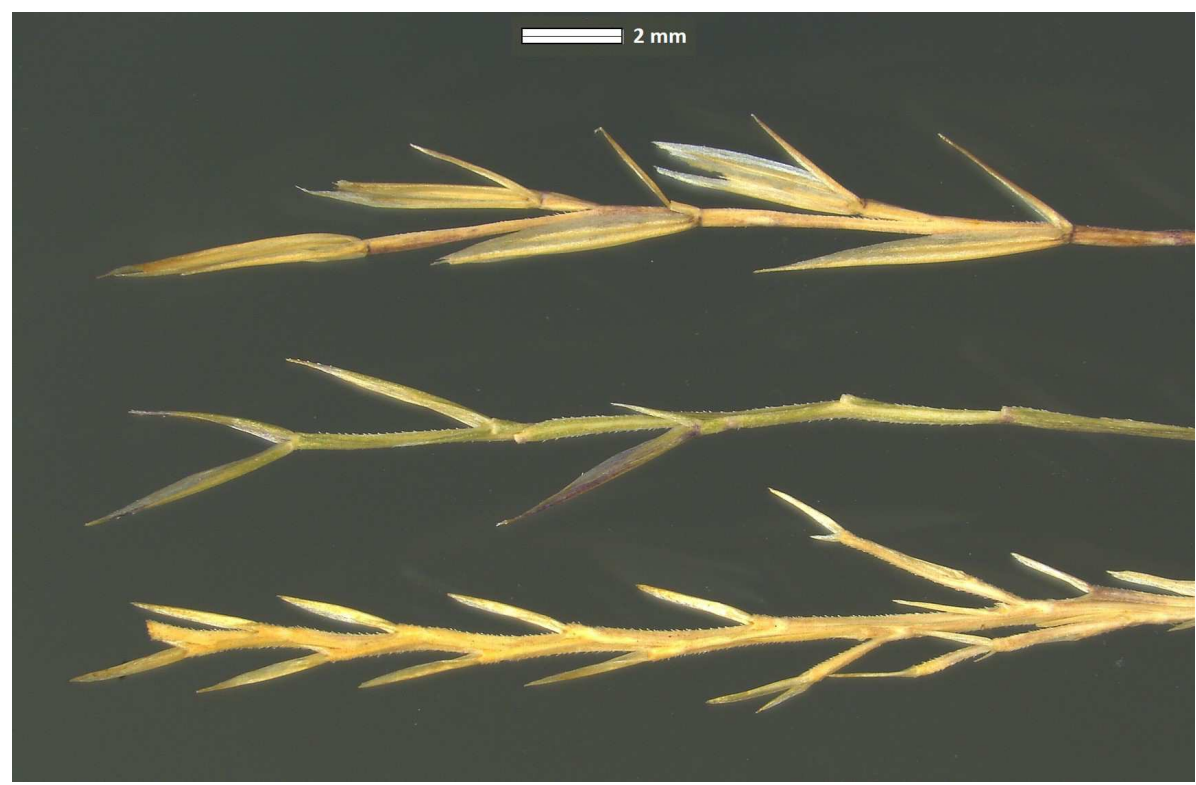

2. ábra A hazai három egércsenkesz faj virágzati főtengelyének csúcsi régiója, pelyvákkal (fentről lefelé: Vulpia bromoides, V. myuros, V. ciliata subsp. ciliata)

Fig. 2 The upper $2 \mathrm{~cm}$ zone of inflorescence of the three Hungarian Vulpia species, with glumes (from top to bottom: Vulpia bromoides, V. myuros, V. ciliata subsp. ciliata)

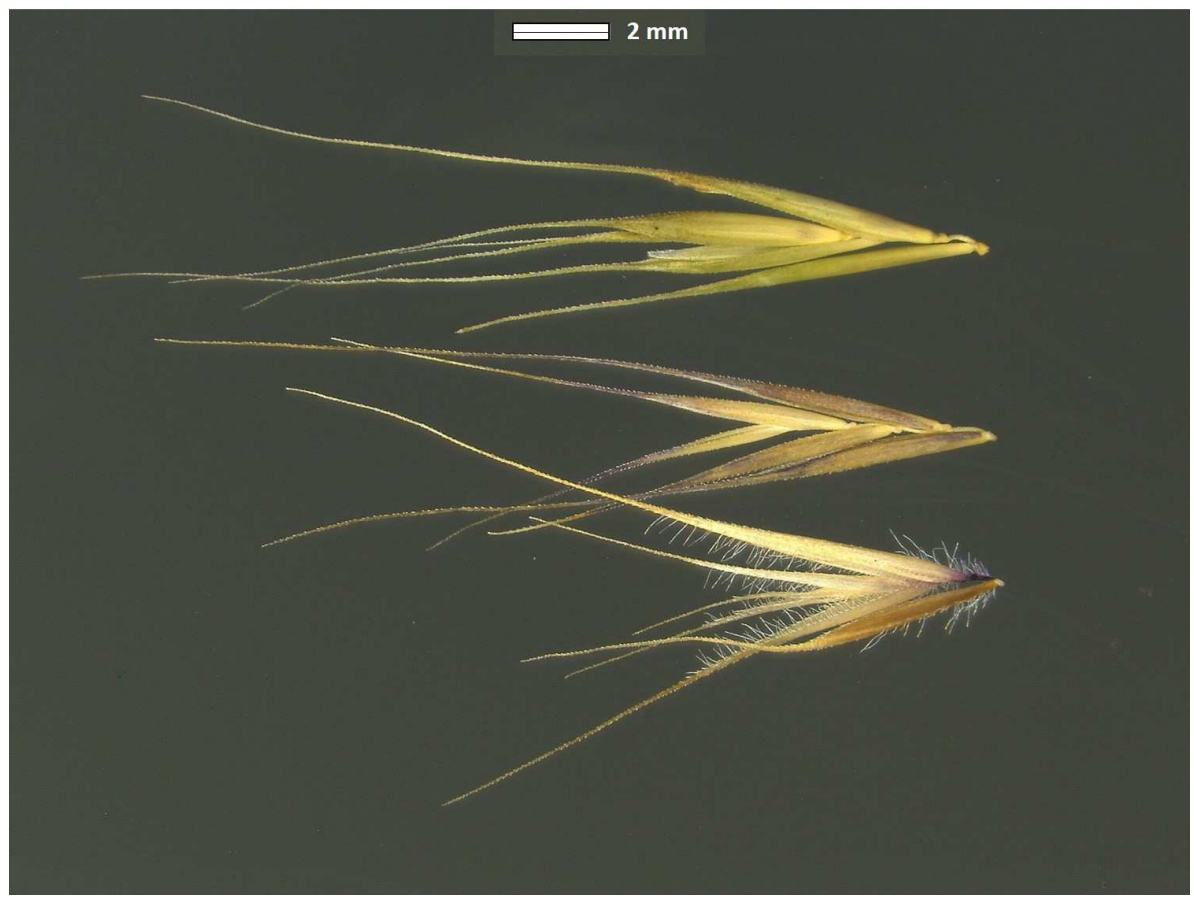

3. ábra A hazai három egércsenkesz faj pelyvák nélküli füzérkéje (fentről lefelé: Vulpia bromoides, V. myuros, V. ciliata subsp. ciliata) Fig. 3 Spikelets (without glumes) of the three Hungarian Vulpia species (from top to bottom: Vulpia bromoides, V. myuros, V. ciliata subsp. ciliata) 
MESTERHÁZY et al. (2021): A Vulpia ciliata morfológiája és magyarországi terjedésének sikere a vasúthálózat mentén

2. táblázat A morfológiai mérések átlag (minimum-maximum) adatai, valamint a Kruskal-Wallis teszt eredményei. A szignifikancia-szinteket a ' $p$ ' oszlop tartalmazza: '*' $p=0,05-0,01,{ }^{\prime * * * \prime} p<0,001$ Table 2 Mean (minimum-maximum) data from morphological measurements and results of the Kruskal-Wallis test. Significance levels are listed in column ' $p^{\prime}$ : '*' $p=0,05-0,01$, $* * * \prime^{\prime} p<0,001$

\begin{tabular}{llllll}
\hline & & V. bromoides & V. myuros & V. ciliata & $p$ \\
\hline 1. & padkák száma/ felső $2 \mathrm{~cm}$ & $5,33(4-7)$ & $6,6(5-8)$ & $11,93(11-14)$ & $* * *$ \\
2. & termés/füzérke száma (db) & $5,13(4-6)$ & $3,8(2-5)$ & $1(1-1)$ & $* * *$ \\
3. & fertilis/sterilis virág (\%) & $85,65(66,67-100)$ & $83,44(50-100)$ & $15,98(12,5-20)$ & $* * *$ \\
4. & alsó pelyva hossza (mm) & $3,88(2,71-4,46)$ & $1,75(1,35-2,91)$ & $0,73(0,44-1,21)$ & $* * *$ \\
5. & felső pelyva hossza $(\mathrm{mm})$ & $6,77(5,83-7,88)$ & $4,16(3,24-4,93)$ & $2,52(1,96-2,93)$ & $* * *$ \\
6. & toklászhossz (mm) & $6,04(4,92-6,71)$ & $5,42(4,53-6,97)$ & $6,01(5,23-6,7)$ & $*$ \\
7. & szálkahossz (mm) & $10,44(6,63-12,37)$ & $10,39(6,24-14,19)$ & $7,31(6,3-9)$ & $* * *$ \\
8. & főttengely vastagság (mm) & $0,29(0,19-0,42)$ & $0,31(0,16-0,5)$ & $0,41(0,33-0,5)$ & $* * *$ \\
\hline
\end{tabular}

3. táblázat A vizsgált jellegek fajpáronkénti összehasonlításának eredménye Mann-Whitney teszttel. A számok a 2. táblázatnak megfelelő jellegeket kódolják, a szimbólumok nélküli számok a $p<0,001$ szignifikancia szintet, a '*' a $p=0,05-0,01$, míg a '**' a $p=0,01-0,001$ szintet jelölik

Table 3 Results of the pairwise comparison of studied traits with the Mann-Whitney test. The numbers encode features according to Table 2, the numbers without symbols indicate $p<0,001$ significance level, the '*' denotes $p=0,05-0,01$ level, and the '**' indicates $p=0,01-0,001$ level

\begin{tabular}{|l|c|c|c|}
\hline & V. bromoides & V. myuros & V. ciliata \\
\hline V. bromoides & & $1^{* *}, 2,4,5,6^{*}$ & $1,2,3,4,5,7,8$ \\
\hline V. myuros & & & $1,2,3,4,5,6^{*}, 7^{* *}, 8$ \\
\hline V. ciliata & & & \\
\hline
\end{tabular}

A fajt a hazai Vulpia kulcsba (KIRÁLY \& MESTERHÁZY 2009) a következőképp illesztettük be:

1a A füzérke alján 1-3 termékeny virággal, tetején 3-7 steril virággal. Az alsó pelyva nagyon rövid pikkelyszerü 0,1-1,3 mm, míg a felső pelyva 1,5-4 mm hosszú, arányuk <0,35. Toklász háta ritkásan hosszú szőrökkel borított, szegélye pillás. A szálka nélküli füzérke 7-10 mm hosszú. A buga főtengelye egyenletesen vaskos (0,3-0,5 mm), felső felében cmként 5-7 padkával. H: 6-45 cm. Th. IV-V. Köves talajú gyomtársulások, vasutak mentén terjedőben. A (D-T, Kis-A, Drávamenti-síkság), NyDt (Zalai-dv.), DDt (Baranyai-dombság, Pécsi-síkság).

V. ciliata Dumort. subsp. ciliata - Pillás e.

1b A füzérke alján 2-5 termékeny virággal, tetején 1-2 steril virággal. Az alsó pelyva hosszabb 0,8-5 mm, míg a felső pelyva 2,5-9 mm hosszú. Toklász kopasz. A buga főtengelye a padkák alatt és felett eltérő vastagságú (0,16-0,5 mm), felső felében a padkák száma cm-ként jóval kevesebb.

2a A virágzat hosszan megnyúlt, legalább 3-szor hosszabb a legalsó bugaágnál. A virágzat alsó részét a felső levélhüvely eléri vagy körülveszi. - A buga 4-35 cm hosszú, legalsó ága 2-7 cm-es, a legalsó ág és a teljes virágzat hosszának aránya $<0,35$. Az alsó pelyva 0,52,5(-3,5) mm, a felső pelyva 3-7 mm, arányuk 0,4. A buga főtengelye teljes hosszában érdes felszínű, felső felében cm-ként 3-4 padkával. T: 10-80 cm. Th. V-IX. Mészkerülő gyepek, parlagok, útszélek. M.e.t. szórv.

V. myuros (L.) Gmel. - Vékony e.

2b A virágzat tojásdad, legfeljebb 2,7-szer hosszabb a legalsó bugaágnál. A virágzat alsó részét a felső levélhüvely nem éri el, a szár virágzat alatti része (0,5-)3-15(-25) cm-en levéltelen. - A buga 2-12 cm hosszú, legalsó ága 1,5-5 cm-es, a legalsó ág és a teljes virágzat hosszának aránya $>0,4$. Az alsó pelyva 2,5-5,5(-6) $\mathrm{mm}$, a felső pelyva $(4,5-) 5,5-$ $9(-10) \mathrm{mm}$, arányuk $>0,5$. A buga főtengelye csak a padkák feletti részen érdes, a virágzat valamivel lazább, a buga felső felében cm-ként csak 2-3 padkával. T: 10-50 cm. Th. VIVII. Mészkerülő gyepek, földutak széle, száraz és üde erdőszegélyek. DK (Bakony, Keszthelyi-hg.), NyDt ritka, DDt (Belső-Somogy, Zselic, Mecsek), terjedőben (?).

V. bromoides (L.) Gray - Déli e. 
A faj leginkább a hasonlóan bolygatott, száraz termőhelyen élő $V$. myuros-szal téveszthető össze (amely a vasutak mellett is gyakori, terjedőben lévő faj), de attól a toklászok tüzetes vizsgálatával a szőrök jelenléte alapján könnyen elkülöníthető (1. és 2 . ábra). A két faj fenológiájában is vannak különbségek: a $V$. ciliata már április közepétől virágzik, és a virágzása csúcsidőszakát általában május elején éri el, azonban a $V$. myuros még virágzás előtti, vegetatív állapotban van ebben az időszakban. A vegetatív hajtások a $V$. ciliata esetében sárgás(vöröses) zöldek, míg a $V$. myuros esetében ekkor még hamvas(-kékes) zöldek. Terméséréskor a $V$. ciliata általában már szalmasárga, száraz, ezért májusban a két faj a színük alapján már messziről is megkülönböztethető. Júniusra viszont a V. myuros is szalmasárga lesz. Mivel termetükben és küllemükben nagyon hasonló fajokról van szó, így felismerésük felületes vizsgálatok alapján ekkor már nagyon nehéz. A V. ciliata esetében a toklász szőrei a növény elszáradása után is jól láthatóak. Júniustól azonban a szemek kiperegnek, a hajtás összetöredezik, nyár közepére már a kórója is eltűnik. Az érőben lévő $V$. ciliata-k bugája eleinte lilásan futtatott, majd megsárgul. A küllemük mellett vasútmenti élőhelyük is hasonló, mindketten a sínek körüli száraz, köves részeket részesítik előnyben (magyarországi cönológiai preferenciájuk vizsgálata folyamatban), de a kötöttebb talajú, nyíltabb, taposott gyomtársulásokban (Mucina et al. 2016 alapján a Polygono-Coronopodion Sissingh 1969-be sorolható állományokban) is felbukkanhatnak.

A V. ciliata subsp. ciliata terméságazatának sajátos morfológiája és a füzérkék fertilissterilis virágainak aránya feltehetően a hozzájárulhat a terjedés sikeréhez. A füzérkékben ui. a fertilis virágok száma jellemzően egy, így arányuk a többi egércsenkesz fajunkhoz képest igen alacsony, 1:6. A steril virágokban a belső toklász sem fejlődik ki, viszont a külső toklász szegélyei erősen pillásak. A pillák a toklászon egy irányba rendeződnek, nem kifelé, hanem befelé, a füzérke belseje felé néznek (tehát elsődlegesen nem a fennakadásban, hanem az összegabalyodásban és a lebegésben segítenek). Ez utóbbi karakteregyüttes könnyített propagulumszerkezetet eredményez, ui. a buga szétesésekor a steril és fertilis részek mint terjedési egységek együtt válnak le a füzérkéről. Az így kialakult V-alakú hegyes, pillás képlet nem csak a zoochoriának, az összegabalyodásnak, azaz a csoportos szóródásnak, de a széllel való szállításnak is kedvez (hiszen ennél az alfajnál csak egy magot tartalmaz és felületnövelő képletekben is gazdagabb). Ezzel hozzájárul az alfaj jobb terjedőképességéhez, expanziójának sikeréhez. A másik alfaj, a V. ciliata subsp. ambigua toklászain ui. nem találunk pillákat, felületük a $V$. myuros és $V$. bromoides toklászaihoz hasonlóan érdesek, de szőrtelenek (WATKINSON et al. 1998). Mindemellett a V. ciliata subsp. ciliata egységnyi hosszú bugáján $\sim 2 \times$ annyi füzérkét hordoz, mint a $V$. myuros vagy $V$. bromoides. Feltehetőleg ennek a terhelésnek köszönhető, hogy a $V$. ciliata bugájának főtengelye a három faj közül a legvaskosabb. A füzérkén belüli alacsony fertilitási arányt a $V$. ciliata így hatékonyan kompenzálja, a meglehetősen expanzív $V$. myuros-szal szemben is (pl. pécsi vasútállomásokon, a sínek környékéről ki is szoríthatja a vékony egércsenkeszt). Korai, május eleji érése pedig segíti a jellemzően késő tavasszal kezdődő vasút menti gyomirtás elkerülését, és túlélésének sikerét. A vasúthálózaton kívüli terjedését egyelőre akadályozhatják a klimatikus viszonyok (mediterrán eredetû faj), illetve a pályatesteken kívüli, relatív előnyt kínáló szezonális gyomirtások hiánya. Ilyen körülmények között ui. a később (jellemzően júniusban), de több termést érlelő, hasonló termőhelyi igényű, de klímára kevésbé érzékeny $V$. myuros-szal szemben hazánkban nem élvez előnyt.

\section{Hazai előfordulás körülményei}

A $V$. ciliata subsp. ciliata, $V$. danthonii (A. \& G.) Deg. néven már JávoRKA (1925) kulcsában is szerepel, aldunai és quarneroi előfordulással. Említésre érdemes, hogy ebben a munkában és 
a később, 1933-1934-ben megjelenő Iconographiában (JÁVORKA \& CSAPODY 1991) sem szerepel magyar név a Vulpia fajok mellett. A faj Magyarországon először a szolnoki vasútállomásról került elő 2016.05.25-én, majd több adata a 2020-as évből származik. Ez annak köszönhető, hogy a szerzők a vasút menti élőhelyek vizsgálatát 2020 -ban végezték nagyobb intenzitással, a növény azonban ennél már korábban is elterjedhetett a vasútjaink mentén. A V. ciliata megfigyeléseink szerint megtalálható a fő- és mellékvágányok közelében is, nem kötődik az átrakodóhelyekhez. Ez alapján terjesztésében a teher- és a személyforgalom egyaránt jelentős szerepet játszhat. Adatai kivétel nélkül a vasútállomásokról származnak, ami azonban a pályaudvaron kívüli vonalszakaszok hiányos kutatásának, valamint a nyílt pályaszakaszokon az apró köves, finomzúzalékos felszín hiányának is köszönhető. A faj a durva zúzalékból felépülő vasúti töltésekről szinte teljesen hiányzik. Leggyakrabban a vasút menti nyílt területek $\mathrm{T}_{4}$-es növényeivel társul (Vulpia myuros, Setaria pumila, Digitaria sanguinalis, Eragrostis minor), de ugyanúgy előfordulnak kora tavaszi efemerek (Saxifraga tridactylites, Erophila verna) társaságában is. A V. ciliata eredeti areáján belül napos lejtőkön, parlagokon (JÁVORKA 1925), meszes talajú száraz gyepek nyíltabb részein (BARINA 2017), kiszáradt folyómedrekben, homokpadokon, száraz bolygatott helyeken, sziklarepedésekben (BOR 1968, KOMAROV 1934) él, európai terjedése mindenütt vasútvonalakon keresztül történt. A vágányok mentén lévő bazaltköves részek gyorsan felmelegedő, gyakran extrém száraz élőhelyek, melyek lehetővé teszik a melegigényesebb mediterrán eredetű, sziklás, kőtörmelékes helyeken élő fajok (Geranium purpureum, Chaenorhinum litorale, Galium murale) elterjedését a kontinens belső részein is. Ezt a terjeszkedést segítik továbbá az utóbbi évtizedek enyhébb telei, amelyek az ősszel csírázó $\mathrm{T}_{1}$ és $\mathrm{T}_{2}$-es gyomok túlélési esélyét növelik a téli időszakban. Mivel a $V$. ciliata-t az ország több régiójában is kimutattuk már, feltételezhetjük, hogy a domb- és síkvidéki régiókban a közeljövőben általánosan elterjedtté fog válni, elsősorban a vasútállomások környékén. Megfigyeléseink szerint a faj egyelőre a vágányok közelében, attól 20 m-es távolságon belül fordul csak elő, de ott tömegessé válhat, a hasonló termőhelyen élő $V$. myuros-t egyes helyeken (pl. Pécs) ki is szorítja. A közelmúltban tapasztalt terjedési potenciálját látva joggal feltételezhetjük, hogy a jövőben a vasútvonalak általánosan elterjedt, gyakori fajává fog válni, de más köves, száraz gyomtársulásokban, illetve felnyíló, vagy nyílt száraz gyepekben is megjelenhet.

Az alábbiakban részletezzük a faj eddigi hazai adatait, illetve azokat a 4. ábrán mutatjuk be:

- Szolnok, vasútállomás: 4. vágány mellett bazaltkőtörmeléken kisebb foltokban. 2016.05.25., Mesterházy A. (8887.1)

- Budapest, Keleti pályaudvar: Kerepesi úthoz közel eső mellékvágányok mentén szálanként. 2016.05.27., Mesterházy A. (8480.4)

- Murakeresztúr, vasútállomás: 5-6. vágányok mellett kőtörmelékes helyeken szórványos. 2020.06.02., Mesterházy A. (9667.1)

- Gyékényes, vasútállomás: 1., 6. és 7. vágányok mellett, köves helyeken kisebb foltokban. 2020.06.02., Mesterházy A. (9767.4)

- Hegyeshalom, vasútállomás: iparvágányok közötti kőtörmelékes helyeken gyakori. 2020.06.09., Mesterházy A. (8068.4)

- Lébény, vasútállomás nyugati részén, sínek közötti kőzúzalékon, kisebb csoportban, elvirágzott, elszáradt egyedek. 2020.07.17., Schmidt D. (8270.2).

- Tapolca, vasútállomás: 1-3. vágányok mellett kőzúzalékon kisebb csoportokban. 2020.06.28., Mesterházy A. (9170.2)

- Pécs, Mecsekalja-Cserkút vasútállomáson a sínek környékén és a rakodók körül (a sínektől $6 \mathrm{~m}$ távolságra is), ill. a legkülső vágány külső szélén, kb. 40 m-es szakaszon, taposott finomtörmeléken tömeges; a sínektől távolabbi, kevésbé zavart érintkező részen már a (virágzó, zöld) V. myuros jellemző. 2020.05.09. Wirth T.-Csiky J. (9974.2) 
- Pécs, Főpályaudvar, az iparvágányok mentén a sínek között és a vágányok mellett, taposott kavicselegyes finomtörmeléken több száz méter hosszan tömeges, itt-ott a V. myuros-szal vegyes állományok, illetve a Megyeri úti átkelőnél, nagyobb foltokban tömeges. 2020.05.18., Csiky J. (9975.1)

- Pécs, Sport utca: a vasúti átkelőhely mentén szórványos, 2020.05.09. Wirth T. (9975.1).

- Pécs, Pécs-Külváros vasútállomás, a vasúti átkelő környékén, főleg a Főpályaudvar felé kb. 100 méter hosszan, taposott kavicselegyes finomtörmeléken általánosan elterjedt, néhol tömeges, a V. myuros a sínektől távolabb is, döntően elkülönülve. 2020.05.20., Csiky J. (9975.1)

- Pécs, Pécsbánya-Rendező vasútállomás, többfelé, taposott finomtörmeléken, mintegy száz méter hosszan, 50 m szélességben tömeges (termésben, szalmasárga), a forgalmasabb helyekről a Bormus tectorum-ot és a V. myuros-t is kiszorította, az érintkező zónákban vegyes állományok is akadnak. 2020.05.20., Csiky J. (9975.2)

- Szigetvár, 6-os Sz. főút, vasútállomás: sínek között néhány egyed, 2020.05.10., Wirth T. (9972.4).

- Szentlőrinc, Hunyadi János utca, vasútállomás: a vasúti sínek között tömeges, 2020.05.10., Wirth T. (9973.4).

- Bicsérd, Külterület, vasútállomás: a vasúti sínek között néhány tő, 2020.05.10., Wirth T. (9974.3).

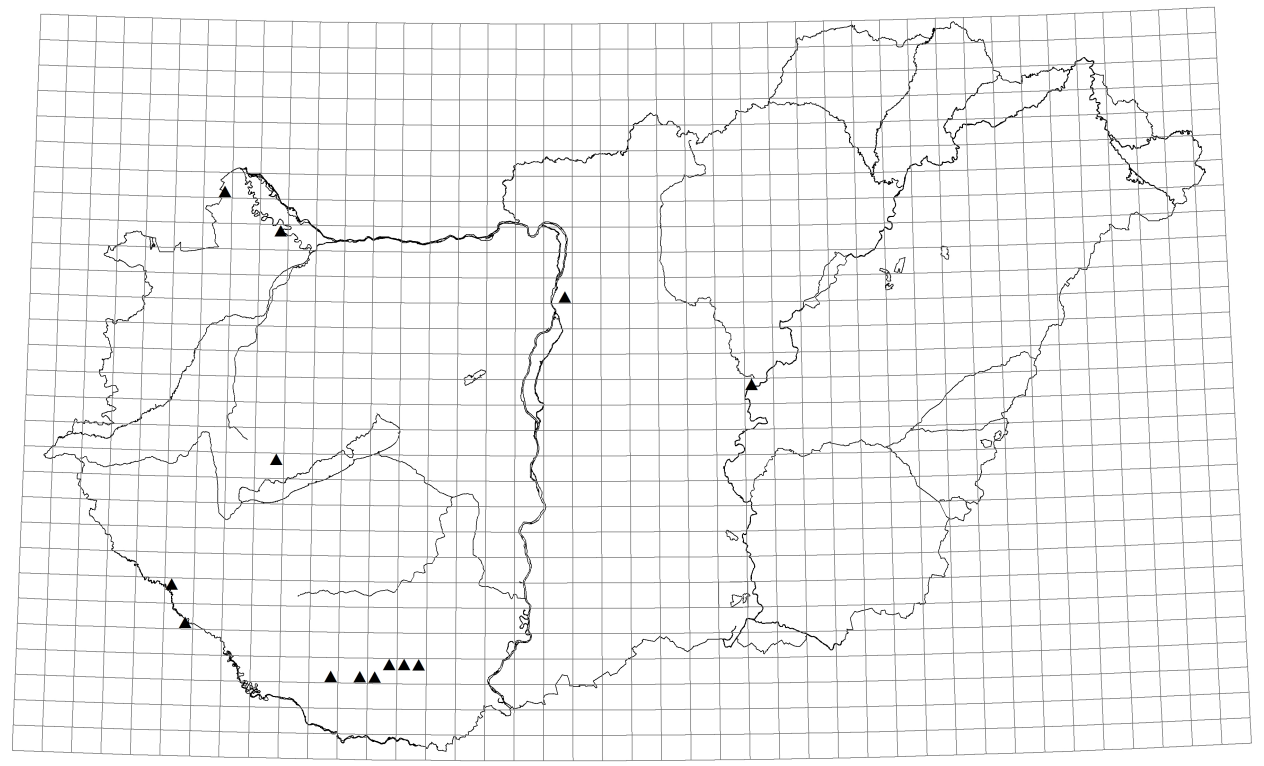

4. ábra A Vulpia ciliata subsp. ciliata elterjedése Magyarországon Fig. 4 Distribution of Vulpia ciliata subsp. ciliata in Hungary

\section{Köszönetnyilvánítás}

Köszönet illeti Jana Táborská-t a $V$. ciliata rajzának elkészítéséért és Rolf Rutishauser-t (Svájc) a faj elterjedésével kapcsolatos irodalmak rendelkezésre bocsájtásáért. Wirth Tamás és Csiky János munkáját az Európai Unió és az Európai Szociális Alap társfinanszírozásával megvalósuló EFOP-3.6.1-16-2016-00004 számú, az 'Átfogó fejlesztések a Pécsi Tudományegyetem az intelligens szakosodás megvalósítása érdekében' c. pályázat támogatta. 


\section{Irodalom}

Anon. (2019): A Bizottság jelentése az Európai Parlamentnek és Tanácsának. A vasúti piac fejlődésének nyomon követéséről szóló hatodik jelentés, a 2012/34/EU európai parlamenti és tanácsi irányelv 15. cikkének (4) bekezdése alapján. 20 pp.

Asmussen-LAnge C. B. \& HeRmann J. (2016): Atlas Flora Danica. Version 1.1. Botanical Society of Denmark. http://atlasfloradanica.dk [Hozzáférés: 2020.02.20.].

BALOGH L. \& Mesterházy A. (2017): Két új adventív faj előfordulása Magyarországon a buzérfélék (Rubiaceae) családjából. - Kitaibelia 22(2): 286-296.

BARINA Z. (ed.) (2017): Distribution atlas of vascular plants in Albania. - Hungarian Natural History Museum, Budapest, $492 \mathrm{pp}$.

BENEDEK M. \& BUDA E (2000): Károlyi Árpád (1907-1972) emlékezete. - Kitaibelia 5(1): 3-8.

Bor N. L. (1968). Vulpia. - In: Bor N. L. \& Guest E. (eds), Flora of Iraq. Vol 9, Ministry of Agriculture Republic of Iraq, Baghdad, pp. 86-90.

Buttler K. P., Thieme M. \& Mitarbeiter (2017): Florenliste von Deutschland - Gefäßpflanzen. Version 9. Frankfurt am Main. - http://www.kp-buttler.de [Hozzáférés 2020.02.20.].

Ciocârlan V. (2000): Flora ilustrată a României. Pteridophyta et Spermatophyta. - Editura Ceres, Bukarest, $1138 \mathrm{pp}$.

Cotton R. \& StACE C. A. (1976): Taxonomy of the genus Vulpia (Gramineae). I. Chromosome numbers and geographical distribution of the Old World species. - Genetica 46: 235-255.

DANCZA I. \& KIRÁLY G. (2000): A Senecio inaequidens DC. előfordulása Magyarországon. - Kitaibelia 5(1): 93-109.

FisCHER M. A., OsWALD K. \& ADLER W. (2008): Exkursionsflora für Österreich, Liechtenstein und Südtirol. 3. Aufl. - Linz: Biologiezentrum der Oberösterreichischen Landesmuseen, $1391 \mathrm{pp}$.

GHIo C. (1978): Vulpia ciliata Dum. sur un terril de charbonnage dans le Borinage. - Dumortiera 9: 20-21.

Hammer O., Harper D. A. T. \& Ryan P. D. (2001): PAST: Paleontological Statistics Software Package for Education and Data Analysis. Palaeontologia Eletronica 4. 1-9.

HANSEn M. J. \& Clevenger A. P. (2005) The influence of disturbance and habitat on the presence of nonnative plant species along transport corridors. - Biological Conservation 125: 249-259.

HASZonits Gy. \& SCHMiDT D. (2018): A potenciálisan inváziós vesszős aggófű (Senecio inaequidens DC.) aktuális elterjedése. - Kitaibelia 23(2): 179-187.

JÁvoRKA S. (1925): Magyar Flóra. Flora Hungarica. - Studium, Budapest, 1307 pp.

Jávorka S. \& CSAPody V. (1991): Iconographia Florae Partis Austro-Orientalis Europae Centralis. Akadémiai Kiadó, Budapest, 576 pp.

Jessop J., DAshorst G. R. M. \& JAmes F. M. (2006): Grasses of South Australia: An Illustrated Guide to the Native and Naturalised Species. - Wakefield Press, Kent Town, South Australia. 554 pp.

Jogan N., Bačič T., Frajman B., Leskovar I., NAGlič D., Podobnik A. \& Rozman B. (2001): Gradivoza Atlas flore Slovenije. - Miklavz na Dravskem Polju: Center za kartiranje favne in flore, Ljubljana, $443 \mathrm{pp}$.

Király G. \& Mesterházy A. (2006): Vulpia C. C. Gmel. - In: Király G. (szerk.), Új Magyar Füvészkönyv. Magyarország hajtásos növényei. Határozókulcsok. Aggteleki Nemzeti Park Igazgatóság, Jósvafő, pp. 509-510.

LANDolt E. (2013) Flora des Sihltals von der Stadt Zürich bis zum Höhronen. Mit Benützung der Daten der „Flora der Stadt Zürich”. - Fachstelle Naturschutz, Kanton Zürich, 1001 pp.

Lauber K., Wagner G. \& GygaX A. (2018): Flora Helvetica - Illustrierte Flora der Schweiz mit Artbeschreibungen und Verbreitungskarten von 3200 wild wachsenden Farn- und Blütenpflanzen, einschliesslich wichtiger Kulturpflanzen 6., 1686 pp.

MAIRE R. (1955): Flore d l'Afrique Nord. Vol III. - Paul Lechevalier Editeur, Paris, 399 pp.

MESTERHÁZy A. (2006): Geranium purpureum Vill. előfordulása Magyarországon. - Kitaibelia 11(1): 65.

Mouterde P. (1966): Nouvelle Flore du Liban et de la Syrie (New Flora of Lebanon and Syria). 1. Texte. Editionsde 1'Imprimerie Catholique, Beyrouth, Lebanon, 503 pp.

Mucina L., Bültmann H., Dierßen K., Theurillat J-P., Raus T., Čarni A., Šumberová K., Willner W., Dengler J., Garcia R. G., Chytrý M., Hájek M., Di Pietro R., Iakushenko D, Pallas J., Daniëls F. J. A., Bergmeier E., Guerra A. S., Ermakov N., Valachovič M., Schaminée J. H. J., Lysenko T., Didukh Y. P., Pignatti S., Rodwell J. S., Capelo J., Weber H. E., Solomeshch A., Dimopoulos P., Aguiar C., Hennekens S. M. \& TichÝ L. (2016): 
Vegetation of Europe: hierarchical floristic classification system of vascular plant, bryophyte, lichen, and algal communities. - Applied Vegetation Science 19 (Suppl. 1): 3-264.

PignatTi S. (2017): Flora d'Italia 1. Seconda ed. - Edagricole, Bologna, 1064 pp.

Poldini L. (2002): Nuovo Atlante corologico delle piante vascolari nel Friuli Venezia Giulia. - Udine: Regione Autonoma Friuli Venezia Giulia, Azienda Parchi e Forestale Regionali; Trieste: Università degli Studi di Trieste, Dipartimento di Biologia, $529 \mathrm{pp}$.

Pyšek P., DAnihelKa J., SÁdlo J., Chrtek J., ChytrÝ M., Jarošík V., Kaplan Z., Krahulec F., Moravcová L., Pergl J., Štajerová K. \& TichÝ L. (2012): Catalogue of alien plants of the Czech Republic (2nd edition): Checklist update, taxonomic diversity and invasion patterns. - Preslia 84: 155-255.

Reich D., BARTA T., PilsL P. \& SANDER R. (2018): Beiträge zur Kenntnis der Gattung Vulpia (Poaceae) in Österreich mit besonderer Berücksichtigung von Vulpia ciliata, neu für Wien und Niederösterreich. - Neilreichia 9: 247-267.

Schмidт D. (2016): Polgár Sándor és az adventívflóra kutatása: Egzotikus flóraszigetek Győrben a 20. század első felében. - Kitaibelia 21(2): 188-197.

STACE C. (2010): New flora of the British Isles. - University Press, Cambridge, $1232 \mathrm{pp}$.

TAmis W. L. M. (2005): Changes in the flora of the Netherlands in the 20th century. - Gorteria Suppl. 6: 1233.

Tison J. M. \& DE Foucault B. (2014): Flora gallica: Flore de France. - Biotope, Mèze, 1196 pp.

VAldÉS B. \& SCHOLZ H. (2009): Poaceae (pro parte majore). Euro+Med Plantbase. The information resource for Euro-Mediterranean plant diversity. - http://ww2.bgbm.org/EuroPlusMed/ [Hozzáférés: 2020.02.20.].

Verloove F. (2021): Vulpia ciliata. - In: Manual of the Alien Plants of Belgium. Botanic Garden Meise, Belgium. - http://alienplantsbelgium.be [Hozzáférés: 2020.02.20.]

Watkinson A. R., Newsham K. K. \& Forrester L. (1998): Vulpia ciliata Dumort. ssp. ambigua (Le Gall) Stace \& Auquier (Vulpia ambigua (Le Gall) More, Festuca ambigua Le Gall). - Journal of Ecology 86: 690-705.

Willis J. H (1970): Handbook of Plants in Victoria. Vol 1: Ferns, Conifers And Monocotyledons. Melbourne University Press, Melbourne, $481 \mathrm{pp}$.

Beérkezett / received: 2021. 05.12. • Elfogadva / accepted: 2021. 07. 02. 